\title{
ВИДОВОЙ СОСТАВ ЛИШАЙНИКОВ И ЭКОЛОГО-СУБСТРАТНЫЕ ОСОБЕННОСТИ КОРЫ КАЛОПАНАКСА СЕМИЛОПАСТНОГО
}

\author{
Скирин Ф.В \\ Тихоокеанский институт географии ДВО РАН, Владивосток \\ Autumn.wayfarer@gmail.com
}

\begin{abstract}
Аннотация: Данная работа направлена на изучение видового состава эпифитных лишайников калопанакса семилопастного (диморфанта) и эколого-субстратных особенностей его коры (ритидома). Работы проводились на юге Приморского края: на полуострове Муравьёва-Амурского, в окрестностях посёлка Заводской (Артёмовский городской округ), на о. Русский и хребте Барачный (Надеждинский район). Заложено 9 пробных площадей. На калопанаксе были отобраны образцы эпифитных лишайников и коры (ритидома) для определения реакции рН. При выявлении видового состава эпифитных лишайников были использованы как собственные данные автора, так и литературные данные. Видовой состав эпифитных лишайников для калопанакса семилопастного включает 46 видов, 24 из которых, приводятся по литературным данным. Отмечено преобладание в видовом составе диморфанта накипных лишайников, что не характерно для форофитов с подобным типом коры. Исследованы эколого-субстратные особенности коры диморфанта для деревьев различного возраста. Структура коры взрослого калопанакса сходна с таковой у дуба монгольского. Также, впервые был определен диапазон $\mathrm{pH}$ коры диморфанта. Отмечено сходство значений кислотности коры исследуемого форофита с таковыми для дуба монгольского, липы амурской и многих других деревьев. Отмечается, что видовое богатство и проективное покрытие лишайников на стволах калопанакса заметно ниже, чем у форофитов, имеющих сходные с ним характеристики коры и произрастающих в той же лесной формации. Отчасти это явление обуславливается особенностями коры молодых калопанаксов, отчасти общим снижением видового разнообразия эпифитных лишайников под антропогенным влиянием. Тем не менее, не удаётся выявить факторы, затрудняющие заселение стволов взрослых калопанаксов эпифитами, в условиях экосистем с высоким видовым разнообразием лишайников. Возможно, причина заключается в химическом составе ритидома дерева. В литературе упоминалось о подавлении роста бактерий золотистого стафилококка настоем коры калопанакса, однако сведений о влиянии химических компонентов его коры на лишайники или их отдельные компоненты не выявлено.
\end{abstract}

Ключевые слова: Приморский край, калопанакс семилопастной, эпифитные лишайники, кислотность коры, структура коры. 


\title{
SPECIES COMPOSITION \\ AND ECOLOGICAL-SUBSTRATE FEATURES \\ OF KALOPANAX SEVEN-BLADED \\ (KALOPANAX SEPTEMLOBUS) \\ (THUNB. EX MURRAY) KOIDZ.
}

\author{
Skirin F. $V$. \\ Pacific Geographical Institute FEB RAS, Vladivostok
}

Summary: This paper represents a study of a species composition of lichens that grows on Kalopanax septemlobus and eco-substrate features of its bark. The area of study covers the south of Primorsky Krai at Muravyov-Amursky peninsula near the Zavodskoy town (Artyomovskiy city district), at Russky island and at the Barachniy ridge (Nadezhdinsky district). 9 sample plots were placed. Epiphytic lichens and three bark samples for the $\mathrm{pH}$ determination was taken from kalopanax. For the identification of epiphytic lichens species composition both author's own data and literature data were used. Epiphytic lichens composition for the Kalopanax septemlobus includes 46 species, 24 of which are given according to literature data. Predominance of crustose thallus lichens over foliose thallus lichens was observed. This fact shows non-typical situation for the phorophytes with this type of bark. Eco-substrate features of kalopanax bark were studied for threes of different ages. Bark structure of the mature kalopanax is similar to bark of Quercus mongolica. Also, there was the first time when $\mathrm{pH}$ range of kalopanax bark was identified. A similarity was noted between the acidity of the bark of the studied forophyte and those for Mongolian oak, Amur linden and many other trees. We have noted that biodiversity and projective cover of epiphytic lichens on kalopanax trunk is noticeably lower than for ones on the other threes that have similar bark properties and those are growing at the same forest ecosystem. Partly this phenomenon is caused by the peculiarities of the bark of young kalopanaks, partly by a general decrease in the species diversity of epiphytic lichens under anthropogenic influence. Nevertheless, it is not possible to identify factors that impede the colonization of adult kalopanax trunks with epiphytes in ecosystems with a high species diversity of lichens. Perhaps the reason is the chemical composition of tree ritidom. In the literature, it was mentioned that staphylococcus aureus bacteria growth was suppressed by infusion of kalopanax bark, however, no information was found on the effect of the chemical components of its bark on lichens or their separate components.

Key Words: Primorskiy Krai, kalopanax seven-bladed, epiphytic lichens, bark structure.

Изучение приуроченности лишайников к определенным, экотопам и субстратам позволяет охарактеризовать особенности экологии отдельных видов и особенности лихенофлоры в целом.

В лесах юга Приморского края основная масса эпифитных лишайников имеет слабую субстратоспецифичность [4]. Большая часть форофитов, также, имеет богатый видовой состав лишайников, в целом, характерный для всей формации, в которой они произрас- 
тают. Для некоторых древесных пород видовой состав лишайников заметно беднее, что связанно обычно с особенностями строения ритидома (сильно отслаивающийся или шелушащийся), или реже с его кислотностью. К таким породам, имеющим бедный видовой состав эпифитов, относится калопанакс семилопастной (диморфант) Kalopanax septemlobus (Thunb. Ex Murray) Koidz. Этот вид относится к реликтам - представители рода Kalopanax произрастали на территории Приморья в раннем миоцене [2]. Занесен в Красные книги РФ (КК РФ) и Приморского края (КК ПК); статус: 3R - редкий вид. Диморфант, в зрелом возрасте обладает стабильной рельефной корой (кора многих деревьев меняет свои характеристики с возрастом), тем не менее, видовой состав лишайников и их проективное покрытие на стволе дерева у калопанакса семилопастного заметно беднее, чем на деревьях со сходными характеристиками коры, произрастающими с ним в одной лесной формации. Причины, ограничивающие заселение его коры лишайниками не ясны, видовой состав лишайников изучен слабо, кислотность коры не изучена. Выявление фактора, ограничивающего заселение лишайниками этого форофита важно для понимая экологосубстратного распределения эпифитных лишайников региона.

Таким образом, цель настоящей работы - Изучить видовой состав эпифитных лишайников калопанакса семилопастного и влияющие на него эколого-субстратные особенности коры.

Для достижения этой цели для калопанакса семилопастного были отобраны образцы лишайников, определена кислотно-щелочная реакция коры для деревьев разного возраста, проанализирована структура коры и её химический состав (по литературным данным).

Калопанакс семилопастной Kalopanax septemlobus (Thunb. ex Murray) Koidz., или диморфант, - в настоящее время единственный представитель рода Kalopanax Miq. (семейство Аралиевые Araliaceae Juss)

При анализе видового состава лишайников любого форофита, важно учитывать его ареал, поскольку с ним тесно связан ареал произрастающих на нём эпифитов. В связи с этим даётся более подробная характеристика диморфанта. Калопанакс - листопадное дерево высотой до 20-27 (редко 30) м с диаметром ствола на высоте 130149 см до 1 м (максимально 1,8м). Ствол и ветви покрыты твёрдыми шипами (особенно молодые растения). Часто встречается в виде поросли от пней или молодых особей. Доживает до 300 и более лет. 
Диморфант имеет весьма протяженный в Восточной Азии ареал в пределах $23-47^{\circ}$ с.ш. и 88-145 в.д.; встречается на Корейском полуострове, Японском архипелаге (до южного острова Рюкю), в Китае и южных частях Приморского края и Сахалинской области. На юге Приморского края он произрастает в кедрово-широколиственных и широколиственных лесах (до высоты 1100м), а в тропических лесах Китая распространен до 2500 м В Приморье диморфант встречается главным образом в бассейнах рек и ручьёв, впадающих в залив Петра Великого, а также на сопредельных территориях южной части края. На протяжении всего ареала для калопанакса характерно чаще всего одиночное или небольшое групповое распределение деревьев; чистых насаждений он не образует. В Приморском крае сообщества с калопанаксом относят к редким, но, тем не менее, они встречаются на довольно больших территориях. Д.Е. Аксенов с соавторами [1] по материалам лесоустройства и этикеткам гербарных сборов выделили 197 закартографированных мест произрастания калопанакса на площади 2,9 тыс. га [2].

Исследования автора проводились на юге Приморского края в дубовых и хвойно-широколиственных лесах в период с мая по июль 2019 г. Было заложено 9 временных пробных площадей. Определён видовой состав эпифитных лишайников. В связи с малым видовым разнообразием и проективным покрытием лишайников, характерным для исследуемого форофита, лихенологические площадки 20х20 см не закладывались. Лишайники отбирались по всей окружности ствола от комля до высоты около 2 м. Исключение составляет площадка 9. Здесь проективное покрытие эпифитных лишайников оценивалось по стандартной методике с применением процентной сетки (полетки). Отобрано 17 образцов коры для определения её кислотно-щелочных свойств. Также были использованы данные о $\mathrm{pH}$, полученные в результате работы по проведению экологической экспертизы при строительстве линейных объектов в 2008-09 годах (5 образцов) и данные о лишайниках, произрастающих на калопанаксе, взятые из работ других авторов $[7,6]$. Видовой состав лишайников и кислотность коры изучались для деревьев разного возраста (диаметр от 5 до $43 \mathrm{~cm}$ ).

Для определения кислотной реакции коры форофитов была использована методика Горшкова [3]. Со ствола дерева, по всей его окружности, на высоте 130-150 см отбирались кусочки сухой коры 


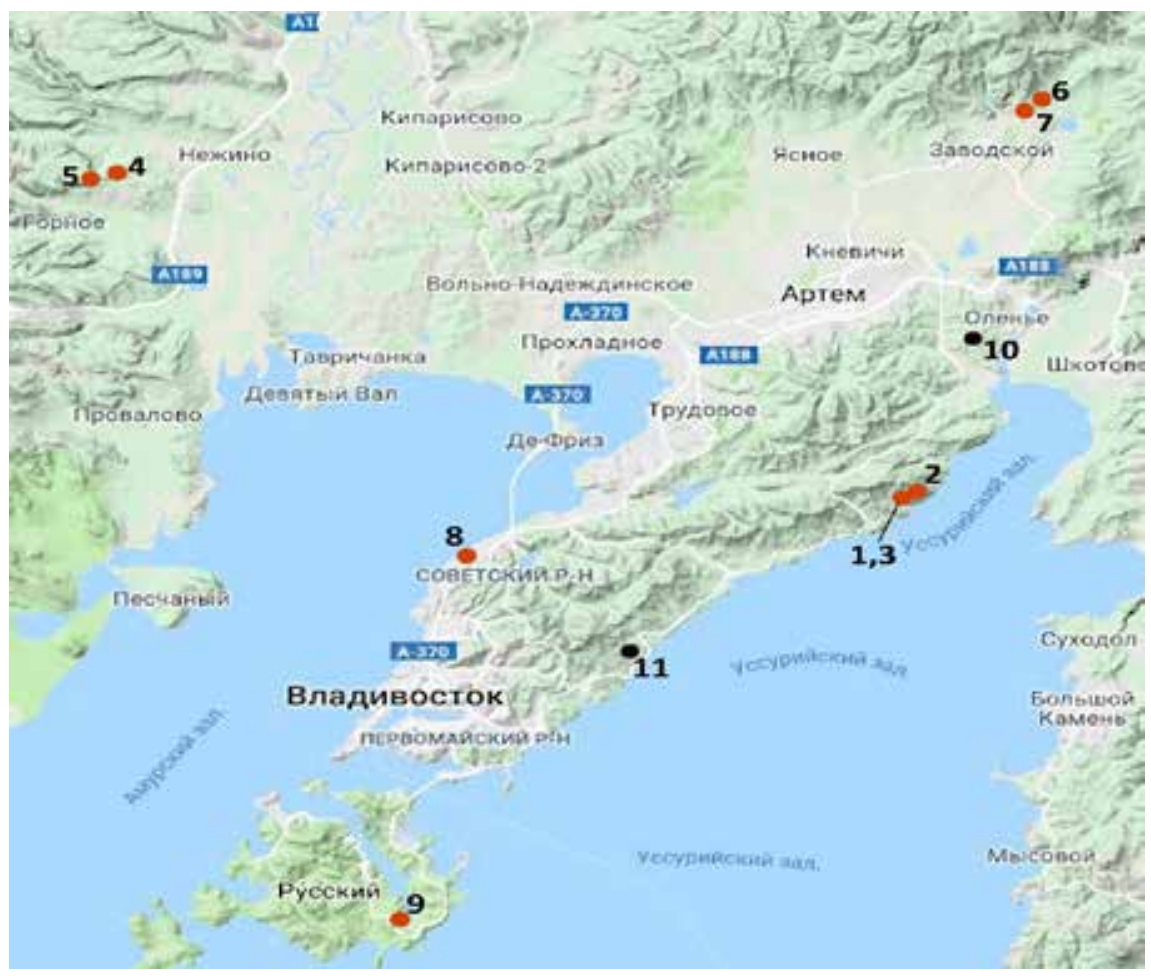

Рис.1 Район исследований

1-9 - места отбора проб 2019, 10,11 - места отбора проб 2008-2009.

без мхов и лишайников, толщиной 1-2 мм. Образцы упаковывались в бумажные пакеты и в таком виде доставлялись в лабораторию. Далее, полученные образцы измельчались до порошкообразного состояния в лабораторной ступке. После этого, пробы заливались дистиллированной водой в соотношении 1:25 и помещались на встряхиватель (почвенный ротатор), где в течение двух часов происходило экстрагирование. Затем, $\mathrm{pH}$ нефильтрованных экстрактов измерялся потенциометрически. Лишайники определялись по стандартной лихенологической методике [8]. Коэффициент втречаемости рассчитывался по формуле:

$$
\mathrm{R}=\mathrm{a} \times 100 / \mathrm{N}
$$

где $\mathrm{R}$ - коэффициент встречаемости, a - число пробных площадок, на которых данный вид встречается, $\mathrm{N}$ - общее число площадок. 
В результате исследования для калопанакса выявлено 46 видов эпифитных лишайников, из них 24 - по литературным данным. Для сравнения, на древесных породах, являющихся эдификаторами в сообществах с диморфантом, например дуба монгольского (Quercus mongolica Fisch. ex Ledeb.) и липы амурской (Tilia amurensis Rupr.), известно более 200 видов. Для сопутствующих пород, таких как бархат амурский (Phellodendron amurense Rupr.) или клён зеленокорый (Acer tegmentosum Maxim.) известно более 80 видов [4]. На калопанаксе преобладают лишайники накипных жизненных форм (30 видов) из родов Lecanora, Pertusaria и Caloplaca. К листоватым жизненным формам относится 15 видов из родов Heterodermia, Phaeophyscia, Collema, Myelochroa и только один к кустистым - Ramalina subgeniculata. При этом большая часть листоватых и кустистых лишайников известна из Уссурийского и Морского заповедников [6,7]. Преобладание числа накипных видов над листоватыми на форофитах с рельефной стабильной корой не характерно. Наиболее часто встречается на исследованном форофите Phaeophyscia hispidula $(\mathrm{R}=33,3 \%)$, несколько реже встречаются Gyalolechia flavorubescens, Lecanora allophana Bacidina phacodes, Biaotra chrysantha, Lecanora chlarotera, Lepraria jackii и Physciella melanchra $(\mathrm{R}=22,2 \%)$. Остальные виды встречаются единично. Все обнаруженные виды являются широко распространёнными и встречаются в различных типах леса на различных субстратах, что указывает на низкую субстратоспецифичность калопанакса.

На большей части исследуемых площадок, число видов лишайников на стволе калопанакса не превышает 4 (площадки 1, 2, 4, 5, 6, 7). На площадке 3 на стволах диморфанта вообще не отмечено лишайников. Малое число эпифитных лишайников (или их отсутствие) на диморфанте на площадках 1-3 и 6-8 связано с общей бедностью видового состава исследованных лесных формаций (от 0 до 4х видов эпифитов на форофите в пределах площадки и её окрестностях). Такая ситуация может быть связана с сильным антропогенным воздействием. Площадки 6 и 7 расположены в 3-х километрах к северо-востоку от комплекса карьеров по добычи скального грунта (пос. Заводской) и в 300-х метрах от трассы магистрального газопровода. Тем не менее, степень влияния этих объектов на лихенофлору исследованных участков не известна и подлежит уточнению. Площадка 8 расположена на территории владивостокского Академгородка и испытывает сильное влияние расположенной в 50 метрах федеральной трассы М60. Для площадок 4 и 5, расположенных в Надеждинском 
районе на Барачном хребте, низкое видовое разнообразие обусловлено молодостью обнаруженных калопанаксов (максимальный диаметр 5 см). Стволики диморфантов такого диаметра плотно покрыты жёсткими шипами, что возможно является препятствием для заселения эпифитных лишайников. На произрастающих в пределах указанных пробных площадей молодых ильмах и дубах (диаметр ствола 6 - 9 см) отмечено от 10 до 14 видов эпифитных лишайников. На более старых деревьях - до 20 видов. С увеличением диаметра ствола площадь не занятой шипами коры калопанакса увеличивается, а сами они расплываются и уплощаются. Кора взрослого калопанакса имеет выражено рельефную структуру и весьма схожа с корой дуба монгольского. Видовое разнообразие эпифитов на площадке 9, расположенной на о. Русский в 300x метрах от форта №11, также достаточно высоко. Здесь же отмечается максимально количество лишайников на коре диморфанта - 9 видов. Видовое богатство коры большинства других произрастающих в пределах площадки форофитов несколько выше - 1620 видов. Проективное покрытие эпифитов на диморфанте также не высоко, около 30\%. У растущего в непосредственной близости дуба с сопоставимым диаметром ствола $-90 \%$.

Следующий этап работы - анализ кислотности коры калопанакса семилопастного. $\mathrm{pH}$ коры диморфанта определён впервые, его значения колеблются от 5,27 до 6,73. Зависимость кислотности коры от возраста дерева прослеживается слабо. Отмечается тренд, указывающий на повышение $\mathrm{pH}$ коры с возрастом дерева (Коэффициент корреляции 0,58$)$.

Чёткая зависимость прослеживается для молодых деревьев с диаметром ствола до 8 см (pH 5,25-5,7). Для деревьев с большим диаметром ствола $\mathrm{pH}$ ниже 6,0 не отмечен. Это явление обуславливается тем, что с увеличением диаметра ствола диморфанта повышается трещиноватость его коры и снижается плотность покрытия его шипами. В результате этого усиливается накопление пыли и растительных остатков, что вызывает повышение кислотности коры [5].

В целом диапазон $\mathrm{pH}$ коры калопанакса сходен с диапазонами $\mathrm{pH}$ дуба монгольского $(4,9-7,0)$, липы амурской $(5,5-6,9)$, осины $(5,1-7,0)$ и многих других древесных пород [4]. Следовательно, кислотность коры также не является фактором, лимитирующим видовое разнообразие эпифитов на диморфанте.

Возможно, угнетающее действие на развитие лишайников оказывают содержащиеся в коре калопанакса химические соединения. Так, 


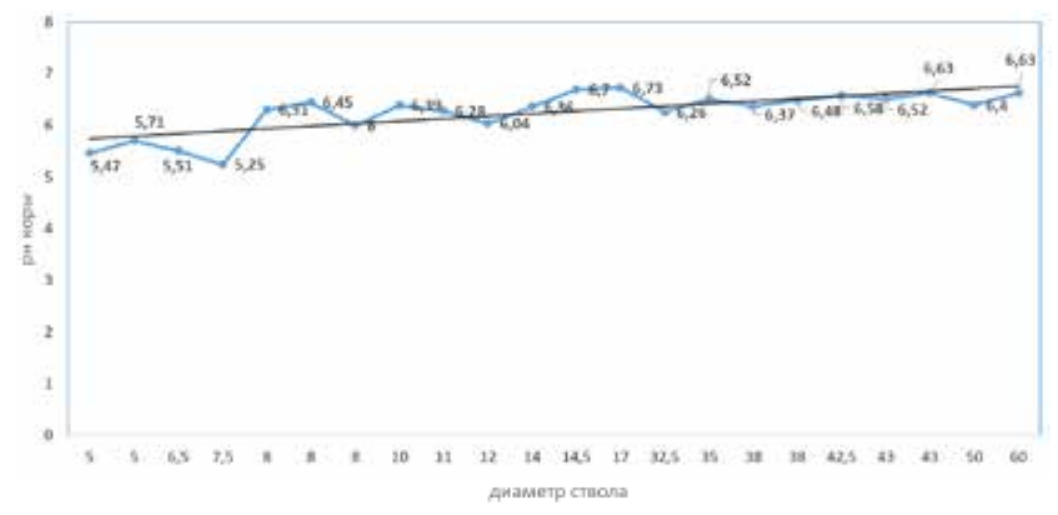

Рис. 2 Зависимость рН коры калопанакса от возраста дерева

по литературным данным, из неё были выделены танины, флавонойды, кумарины, эфирное масло и гликозиды, а также два сапонина калосапонин и калотоксин $[10,11]$. Есть сведения, что настой коры диморфанта подавляет рост золотистого стафилококка в опытах ин витро [9], однако сведений о влиянии содержащихся в ней химических веществ на лишайники или их компоненты нет.

Таким образом, в результате исследования был выявлен видовой состав эпифитных лишайников для калопанакса семилопастного, включающий 46 видов, 24 из которых отмечены по литературным данным.

Выявлен диапазон рН коры диморфанта, он составляет 5,256,7. Эти значения сходны с таковыми для дуба монгольского, липы амурской и многих других форофитов.

Отмечено, что видовое богатство и проективное покрытие лишайников на стволах калопанакса заметно ниже, чем у форофитов, имеющих сходные с ним характеристики коры и произрастающих в той же лесной формации. Максимально, на отдельном стволе было обнаружено 9 видов лишайников, для произрастающих на той же площадке дубах отмечено от 16 до 20 видов.

Выявить факторы, оказывающие влияние на заселение эпифитами взрослых диморфантов не удалось, возможно, причина заключается в химическом составе коры дерева. В литературе упоминалось о подавлении роста бактерий золотистого стафилококка настоем коры калопанакса, однако сведений о влиянии химических компонентов его коры на лишайники или их отдельные компоненты не выявлено. 
Таким образом, из факторов, ограничивающих заселение диморфанта лишайниками, достоверно выявлено только влияние структуры ритидома в молодом возрасте (до диаметра 8-9см).

Более полное выявление видового состава эпифитных лишайников калопанакса семилопастного и определение других факторов, его ограничивающих, будет проведено в ходе дальнейших исследований.

\section{Литература}

1. Аксенов, Д.Е. Выделение лесов высокой природоохранной ценности в Приморском крае. Категории, важные для сохранения растительного покрова / Д.Е. Аксенов, М.Ю. Дубинин, М.Л. Карпачевский [и др.]. - Владивосток; Москва: Изд-во МСоЭС, 2006. $-186 \mathrm{c}$.

2. Гладкова, Г.А.; Редкие растительные сообщества с калопанаксом семилопастным на острове Русский (Южное Приморье) / Л. А. Сибирина; Г.Н. Бутовец // Вестн. ДВО РАН. - 2015. - № 1. - С. 34-44.

3. Горшков, В. В. Использование эпифитных лишайников для индикации атмосферного загрязнения (Методические рекомендации) / В. В. Горшков. -Апатиты, 1991. $-195 \mathrm{c}$.

4. Скирин, Ф. В. Перспектива использования эпифитных лишайников в качестве индикаторов кислотности древесной коры в условиях Южного Сихотэ-Алиня /Ф.В. Скирин // Географические и геоэкологические исследования на Дальнем Востоке: материалы XV молод. конф. с элементами научной школы, Владивосток, 1112 окт. - Владивосток: Дальнаука, 2018. - Вып. 13. - С. 61-68.

5. Скирин, Ф. В., Эпифитные лишайники как показатели состояния приземного воздуха в пригородных лесах полуострова Муравьёв-Амурский / И. Ф. Скирина // географические и геоэкологические исследования на дальнем Востоке. Вып. 3. - Владивосток: Дальнаука, 2007. - С 15-26.

6. Скирина, И. Ф. Лишайники / И. Ф. Скирина, И. М. Родникова // Флора, растительность и микобиота заповедника «Уссурийский». - Владивосток: Дальнаука, 2006. - C. $235-262$.

7. Скирина, И. Ф., Лишайники Дальневосточного морского заповедника, включённые в Красные книги России и Приморского края / И. М. Родникова, Ф. В. Скирин // Биота и среда заповедников Дальнего Востока = Biodiversity and Environment of Far East Reserves. - 2015. - № 3. - С. 125-141.

8. Флора лишайников России: Биология, экология, разнообразие, распространение и методы изучения лишайников / отв. ред. М. П. Андреев, Д.Е. Гимельбрант. М.; СПБ.: Товарищество науч. изд. КМК, 2014. - 392 с.

9. Тхэсоп, Чхве. Лекарственные растения / Чхве Тхэсоп; пер. с корейс. В.Н. Дмитриевой и др. - М.: Медицина, 1987. -605 с.

10. Choi Myung-Suk. Variation of Kalosaponin Contents in Plant Parts and Population of Native Kalopanax septemlobus (Thunb.) Koidz /, Ki-Won Kwon, Cheol-Ho Lee // Korean Journal of Pharmacognosy. - 2000. - Jun, 31(2). - P. 203-208.

11. Tae, Kyung Hyun. The pharmacology and clinical properties of Kalopanax pictus / Kim Ju-Sung // Journal of Medicinal Plants Research. - 2009. - Vol. 3(9). - P. 613-620.

\section{4}




\section{Reference}

1. Aksenov, D. E., Skvortsov V. E., Smirnov D. Yu., Yanitskaya T. O. Videlenie lesov visokoy prirodoochrannoy tsennosti v Primorskom krae. Kategorii, vazhnie dlia sokhraneniia rastitelnogo pokrova. [Mapping high conservation value forests of Primorsky kray, Russian far east. Categories important for preservation of flora and vegetation.]. / M. Yu. Dubinin, M. L. Karpachevskiy, N. S. Liksakova [et al] - Vladivostok; Moskow: Publ. MSoES, 2006. - 186 p. (in Russian).

2. Gladkova, G.A., Redkie rastitelnye soobshestva s kalopanaksom semilopastnym na ostrove Russkiy (Yuzhnoe Primorie) [Rare plant communities with Kalopanax septemlobus on the Russian Island (Southern Primorye).] / L.A. Sibirina, G.N. Butovets // Vestnik DVO $R A N$. - 2015. - N. 1. - P. 34-44. (in Russian).

3. Gorshkov, V. V. Ispolzovanie epifitnykh lishaynikov dlia indikatsii atmosfernogo zagriaznenia (Metodicheskie rekomendatsii). [Using of epiphytic lichens for atmospheric pollution indication (Methodical recommendations).] - Apatity, 1991. - 195 p. (in Russian).

4. Skirin, F.V. Perspektiva ispolzovaniia epifitnykh lishaynikov v kachestve indikatorov kislotnosti drevesnoy kory v usloviyakh yuzhnogo Sikhote-Alinia [Possibility of using the epiphytic lichens as tree bark indicator on south Sikhote-Alin] materialy XV molodezhnoy konf. s elementami nauchnoy shkoly "Geograficheskie I geoekologicheskie issledovaniya na Dalnem Vostoke" [materials of XV youth conf. with elements of scientific school "Geographycal and geoecological research in Far East region"]. - Vladivostok: Dalnauka Publ., 2018. - Vol. 13. - P. 61-68. (in Russian).

5. Skirin, F.V., Epifitnye lishayniki kak pokazateli sostoiania prizemnogo vozdukha v prigorodnykh lesakh poluostrova Muravyev-Amurskiy [Epiphytic lichens as indicators of surface air condition in suburban forests of Muravyov-Amursky peninsula.] / I. F. Skirina // materialy XV molodezhnoy konf. s elementami nauchnoy shkoly "Geograficheskie I geoekologicheskie issledovaniya na Dalnem Vostoke" [materials of youth conf. with elements of scientific school "Geographycal and geoecological research in Far East region"]. - Vladivostok: Dalnauka Publ., 2007. - Vol. 3.- P. 15-26. (in Russian).

6. Skirina, I. F., Lishayniki [Lichens] // Flora, rastitelnost i mikodiota zapovednika «Ussuriyskiy» [Flora, vegetation and microbiota of «Ussuriyskiy» reserve.]. / I. M. Rodnikova // Vladivostok. Dalnauka Publ., 2006. pp. 235-262.

7. Skirina, I. F., Lishayniki Dalnevostochnogo morskogo zapovednika, vklyuchennie v Krasnie knigi Rossii i Primorskogo kraia. [Lichens of Far Eastern State Reserve included in Red books of Russia and Primorskii Krai] / I. M. Rodnikova, F. V. Skirin //Biota I sreda zapovednikov Dalnego Vostoka - Biodiversity and Environment of Far East Reserves. 2015. No. 3 pp. 125-141.

8. Flora lishaynikov Rossii; biologiia, ecologiia, raznoobrazie, rasprostranenie I metody izucheniia lishaynikov. [The lichen flora of Russia: biology, ecology, diversity, distribution and methods to study lichens.], M.; SPB.: partnership of scientific publications KMK, 2014. - 392 P. (in Russian).

9. Tkhesop Chkhve. Lekarstvennye rasteniia [Medicinal plants]; in trans. from korean. V. N. Dmitrieva et al. - M.: Medecine, 1987. - 605 P.; (in trans.)

10. Choi Myung-Suk. Variation of Kalosaponin Contents in Plant Parts and Population of Native Kalopanax septemlobus (Thunb.) Koidz /, Ki-Won Kwon , Cheol-Ho Lee // Korean Journal of Pharmacognosy. - 2000. - Jun, 31(2). - P. 203-208.

11. Tae, Kyung Hyun. The pharmacology and clinical properties of Kalopanax pictus / Kim Ju-Sung // Journal of Medicinal Plants Research. - 2009. - Vol. 3(9). - P. 613-620. 